\title{
INDUSTRIAL PRODUCTION INDEXES AS TOOLS IN REGIONAL ANALYSIS
}

\author{
Carl W. Hale*
}

\section{Introduction}

Economic thought since the end of World War II has produced a growing body of theoretical formulations in the area of regional economic development and growth. 1 The theoretical problems of the lagging region of the developed nation have been extensively considered in economic literature; however, the construction of measures of regional growth necessary to the implemention of regional policy has tended to lag behind the development of regional theory. In short, the needs of regional planners have only been partially served by current measures of economic activity.

Although a considerable body of literature has grown up dealing with states and regional product accounts, a perusal of the relevant articles produces little mention of regional production indexes. ${ }^{2}$ Despite this lack of professional attention, a number of such indexes are now being regularly computed in the United States. 3

It is the purpose of this paper to present an example of a state or regional industrial production index, along with a discussion of its construction, which utilized only state (or local) data; and which could stand alone as an analytical tool, but which would also be a desirable adjunct to any system of regional accounts. ${ }^{4}$ The emphasis here will be placed on state or regional data because it would seem that regional indexes utilizing national series, national weights, or national coefficients of any form a re a contradiction of the regional concept. While a number of production indexes exist at the state level, the Texas Industrial Production Index will be used as an example of what a regional index might look like because the production series and weights used in the compiling of this index are all based on state data.

The industrial production index is a particularly flexible tool of regional economic analysis because, if constructed from monthly or quarterly data, it permits a considerable degree of disaggregation as well as the seasonal and cyclical variations in the physical output of the regional economy. Much of what is interesting and unique about particular regions appears in the seasonal and cyclical movements of regional economic activity--movements that can only be meaningfull measured by monthly or quarterly data. A regional production index provides a measure of long-run production trends as well as a current monthly estimate of industrial production. Moreover, from the standpoint of regional analysis, an important contribution of the component indexes of an aggregate production index is that they provide an overview of a state's industrial structure. ${ }^{5}$

Furthermore, it will be argued that the industrial production index will serve as a basis for evaluating and developing regional development programs.

*Department of Economics and Geography, Auburn University. The Texas Industrial Production Index reflects the work of a number of persons associated with the Research Department of the Federal Researve Bank of Dallas. The 1963 revision of the index upon which this article is based particularly reflects the work of Weldon C. Neill and La Homa Riederer. 
The data furnished by a well developed regional industrial production index would be useful in what Hoover and Chinitz have called vertical and horizontal analysis. 6 Vertical analysis deals with the internallinkages of the regional economy while horizontal analysis involves interregional and/or locational a rguments. Because of their relative simplicity, industrial production indexes could be developed for each state and for Standard Metropolitan Statistical Areas (SMSA's). Such a possibility does not seem to exist for such measures as a gross state product, although the Department of Commerce has developed a quarterly series of State (and SMSA) Personal Income. 7 Furthermore, a comparison of the regional production index with wage payments, personal income payments, construction indexes and retail sales data would present an approach to vertical analysis, and in addition would be a useful tool for describing regional economic change. 8

The technique of constructing a regional industrial production index depends on availability of particular types of data at the state or SMSA level. Furthermore, possible latitude of discression in selecting weighting patterns for the regional data is limited by the procedures used by the staff of the Board of Governors of the Federal Reserve System; otherwise the regional index would not be comparable to its national counterpart. Three possible data classes may be used in construction of a state industrial production index: (1) the use of actual state production data, (2) the use of state input data (manhours and/or electrical power consumption adjusted for productivity), and (3) the use of national production series weighted by state or regional weights (variant of this approach is the use of state manhours or electrical industrial power consumption adjusted to national productivity factors. $)^{9}$

Production data is available for the mining and utility sectors; however, the manufacturing sector presents data problems. Although some manufacturing production series a re available on a monthly basis (petroleum refining for instance), some kind of factor input data has to be used as a proxy for at least some of the manufacturing production subindexes. Probably the best proxy series general available are manhours or electrical power consumption.

The use of national series with state or regional weights is an unacceptable alternative, as all the competitive advantages and efficiencies of the region are ignored. 10 The use of national productivity coefficients and state input data (manhours or electricity) can be better defended on grounds that such coefficients are more stable over time than the alternative state weighting patterns, but here again critical assumption have to be made with respect to both the industry mix and consistency of productivity factors among regions.

The only "regional" solution to this problem is to use all regional data. Either manhours or electrical power comsumption could be used as proxy input where actual production data does not exist at the state level. The manufacturing sector of the Texas production index is based on manhours. This measure has the advantage of being collected in a uniform manner for all states tes and SMSA's. 12 Thus the use of manhours data would furnish the basis for uniform data input for state or regional indexes. ${ }^{13}$ Actual production data a re used for the mining and utility sectors of the Texas Industrial Production Index.

\section{Construction of The Index}

The approach to developing a regional production index suggested in this paper, is that taken by the Federal Reserve Bank of Dallas. In this case the 
Bank has institutionalized an industrial production index based on Texas establishment data composed of 24 subindexes clustered and weighted in the following fashion:

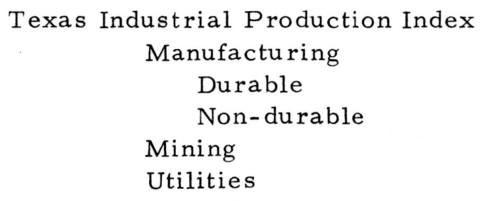

This particular breakdown has the virtue of being symmetrical with that used in the national industrial production index developed by the staff of the Board of Governors. In generalized form a regional industrial production indexutilizing input data such as manhours or electrical power series, would take the following form. We have a number of industries $\mathrm{i}=1 \ldots \mathrm{n}$, with subscripts, $B$, and $t$, which refer to the index base and time periods respectively and where:

$$
\begin{aligned}
\overline{w_{i}} & =\text { annual value added, } \\
\overline{\mathrm{P}_{\mathrm{i}}} & =\text { annual productivity coefficient index, } \\
\overline{\mathrm{M}_{\mathrm{i}}} & =\text { annual manhour index, } \\
\overline{\mathrm{Q}_{\mathrm{i}}} & =\text { annual production index, } \\
\mathrm{m}_{\mathrm{i}} & =\text { monthly manhours } \\
\mathrm{P}_{\mathrm{i}} & =\text { monthly productivity coefficient index, } \\
\mathrm{M}_{\mathrm{i}} & =\text { monthly manhours index, } \\
\mathrm{Q}_{\mathrm{i}} & =\text { monthly production index, } \\
\Delta \mathrm{P}_{\mathrm{i}} & =\text { monthly productivity index change, } \\
100 \frac{\mathrm{m}_{\mathrm{it}}}{\mathrm{m}_{\mathrm{B}}}=\mathrm{M}_{\mathrm{it}} \text { and, } &
\end{aligned}
$$

The subindexes are agg regated in the following manner:

$$
\begin{aligned}
& \sum_{i=1}^{n} Q_{i t} w_{i_{B}}=\text { aggregated index, where: } \\
& \overline{w_{i_{B}}}=w_{i_{B}}=\text { industry weight. } \\
& \frac{\bar{Q}_{i_{B}}}{}
\end{aligned}
$$

The productivity coefficient index is developed in the following manner, where both terms a re obtained from either the Census or the Survey of Manufactures:

$$
\begin{aligned}
& \overline{\mathrm{S}}_{\mathrm{it}}=\text { annual shipments index, } \\
& \overline{\mathrm{C}_{\mathrm{it}}}=\text { annual price index, }
\end{aligned}
$$




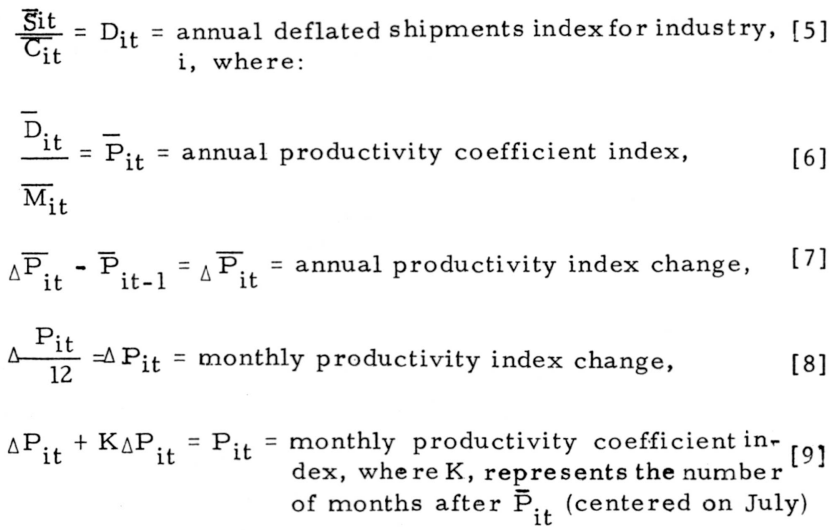

The primary building blocks of the Texas index are the production and manhours series, upon which the monthly variations of the index are based. The actual levels of the proxy manhour subindexes are determined by labor productivity adjustments described in equation [6] through [9].

The computation of annual productivity indexes for each manhour series is one of the more crucial procedures involved in developing a regional production index. The adjusting or "benchmarking" the level of the subindexes, requires the computation of productivity factors based on state data. The numerator of this ratio is the deflated value of shipments (from Census and Survey of Manufactures) at the two digit SIC level. 14 State manhours data (Bureau of Employment Security-- Texas Employment Commission) were used in the denomination of the ratio. These coefficients are developed for industry groups and because of shift effects, between industries within the groups, reflect both changes in labor productivity within industries and changes of the industrial structure within industry groups.

An important step in the computation of annual productivity factors is the construction of a state deflator based on the Wholesale Price Indexes and other relevant price data. 15 Altogether some 74 price indexes were collected and weighed to develop deflators for the 17 productivity factors developed for this production index. The underlying procedure involved in computing the annual deflators for the state was based on the selection of representative 4 -digit SIC industries in each 2 -digit SIC industry group and the assignment of a representative price deflator to each of these weights. These categories selected as being characteristic of the industry group were then used as deflators for the shipments value of the entire industry group. Labor productivity is sensitive to the phases of the business cycle, as are the proxy manhours indexes, thus productivity estimates must be made annually if an acceptable state production index is to be developed. 16 Quarterly estimates of productivity would be required to capture the vagrancies of the business cycle fully.

The Texas Industrial Production Index utilized value added weights adjusted for changes in physical production from the base period (1957-59). 17 The various measures of value added for the industrial sectors used in this paper are homogeneous in that they exclude the current inter-industry flows. In this paper two weighing periods have been used for the Texas Industrial Production Index, 1958 and 1963. In both years the value added figures for each industry were deflated by their respective production indexes. (See Tabbe I). Ideally this method would prevent double counting of the quantity dimen- 
sion of the value added figure. As can be seen from Table I, pronounced differences are apparent between an unadjusted value addedweighting pattern and the actual Texas Indexweighting pattern which takes into account changes in physical output. Changes in quantity are carried forward by the production indexes themselves and ideally the weights applied to the data should only reflect the price component of the value added category.

The Census method of calculating value added is an approximation of the net contribution of an industry to the economic activity of the state. Unfortunately, the concept of value added is somewhat ambiguous when applied to three such divergent sectors as manufacturing, mining, and utilities. Furthermore, the Bureau of the Census does not compute value added for the utility sector.

The Census's definition for value added used in computing the weights for the manufacturing sector follows: value added is equal to the value of shipments (net selling values, f. o. b. plant after discounts and allowances and excluding freight charges and excise taxes, andincluding all merchandising operations) less cost of materials, supplies, containers, fuel, purchasedelectric energy, contract work let, plus the net change in inventories. In contrast the Census of Mineral Industries definition of value added includes current capital expenditures (less machinery) and excludes net changes in inventories. The Census value added weights are gross weights in that they do not net out capital consumption and the purchase of certain business services. Thus, the Census value added figures overstate the actual current contribution of a particular industry.

The value added computation for the utilities sector differs from the othe $r$ value added definitions. Since there are no Census computations of value added for either electric or gas utilities, these computations had to be made from scratch. Utilities, as manufacturing industries, produce a whole basket of services as well as energy. In fact, much of the uniqueness associated with the public utility arises from the transportation services they provide, and for this reason it is proper to price utility sales c.i.f. rather than f. o. b. At the state level an additional problem arises when the interstate exports of a utility are delt with. As pricing is c.i.f. value added computions refer to user prices, yet generation or processing costs are centered in the exporting state, while distribution and transmission costs may occur anywhere inside or outside the exporting state.

The problem was handled in two ways with respect to Texas natural gas and electric utilities. In the case of natural gas utilities, c.i.f. value added was calculated directly for utilities (distributors) operating only in Texas; in the case of long distance transmission companies, a prorated share of total c. i.f. value added (based on interstate transmission companies capital investment in Texas compared with the nation) was used to estimate transmission company value added in Texas. The technique of prorating was required in the latter case because company rather than establishment data was used to make utility value added estimates. It was assumed that value added by interstate transmission companies in Texas was proportional to capital invested in Texas by interstate transmission companies. This apprcach allows for the appropriation of c.i.f. value added by each state having a portion of the utilities transmission capital plant or power stations--regardless whether any natural gas was produced or distributed in the state. In the case of electric power, value added was computed for each producing utility operating within the state by using c.i.f. pricing for each class A \& B public and private utility. Here again company rather than establishment data had to be used and 
a value added-KWH's ratio was developed for all utilities involved, and this was applied to all $\mathrm{KWH}^{\prime} \mathrm{s}$ produced in Texas to obtain a value added figure for Texas operations only.

Although no method of establishing the overall error in the Texas Indus trial Production Index has been established it is possible to obtain a measure of error for past segments of the index as well as some idea about the range of errors involved in the current years estimates of industrial production. Errors in the annual productivity factors can be estimated for the numerator of that ratio. (See Table II). Manhour figures obtained form the Bureau of Employment Security a re based on "cut-off" sampling techniques rather than random sampling; therefore, no probability error term can be developed for the denominator of the ratio. However, the annual data used in the denominator has itself been adjusted to a nearly complete enume ration of workers made during the first quarter of each year. Thus, the error in this annual figure may be assumed to be nominal and the error term for the numerator of the ratio may be considered to be representative of the error term for the productivity coefficient.

\section{Horizontal and Vertical Analysis}

One of the more standard applications of the horizontal approach is shift analysis. 18 The use of the 23 industrial components of the Texas Industrial Production Index in a shift analysis of the industrial structure of the state is illustrative of the use that can be made of the idustrial production data series. The analysis presented in Table III covers the period February, 1961, to May, 1966--the early part of the most recent business expansion, a period associated with rather rapid expansion of industrial activity and for the most part free of severe inflationary problems.

Shift analysis is based on the assumption that regional changes in economic activity can be broken down into three components--the national growth component, the industry mix component, and the regional share component. The summary measure reflecting these categories is the toal change effect. The national growth component is a hypothetical effect which shows what the regions growth for a particular sector would have been had the sector grown at the same rate as all industry in the nation. The Industry mix component reflects the differential rate of growth of the regional industry as compared with the nation total of all industry. The regional share component reflects the differential growth rates associatedwith the same industry in both the region and the nation.

Looking at Table III, SIC Code 36 (Electrical Machinery), the analysis indicates that this Texas industry experienced a 250.6 percentage point increase between February 1961 and May 1966. Using the shift-share argument this increase in output was partioned into three components. The national growth component of 108.6 percentage points indicates growth in the state industry associated with the overall expansion of economic activity in the nation; in this case we would expect the national growth component to be large because we are dealing with a time period associated with a national business expansion. The industrial mix component showed an increase of 36.9 percentage points reflecting the fact that the electronics industry was an above average growth industry during the period under consideration. Finally the regional share component of 205.2 percentage points indicates that the Texas industry experienced a real competitive advantage with regard to the production of electronic components.

Shift analysis performed over long discrete periods of time, i.e., bet- 
ween Census periods, may produce a bias in the component measures which may severely jeopardise the descriptive and analytical value of shift analysis. This condition arises because the component effects used in shift analysis are not independent of the phase of the business cycle, thus the selection of the initial and terminal points of the analysis are important. For this reason it is desirable in shift analysis to use either monthly or quarterly data so that the analysis will correctly reflect the phases of the business cycle. ${ }^{19}$

Shift analysis studies based on employment changes show that Texas as well as much of the southwest has historically registeredindustrial mixeffects that are weak relative to the regional share effects experienced by the state. However, the more current analysis presented in Table III and Table IV suggests that this situation is being altered to some degree. That is, the states relatively stronger regional share effect may be weakening in key sectors.

In order to put this argument into its historical context Table IV presents the industry mix and regional share effects for five business expansions beginning after the end of World War II and ending with the early phases of the military escalation in Viet Nam. This historical analysis suggests that regional share components have indeed been important in explaining industrial development in Texas. At least where the economic expansions are being considered it is clear non-durable manufacturing, mining, and utilities all show relative strength in the regional share component. This is most clear in the case of nondurable manufacturing and mining which reflects the historical dependence of the industrial segment of the Texas economy on the petroleum and natural gas industry. The industrial structure of Texas and the southwest, during the period deltwith in this analysis, may still be characterized as being raw material oriented with very important non-durable manufacturing sector showing strength in the chemical and petroleum refining industries which are directly linked to the mining sector of the Texas economy. Because of the dominance of the mineral industries in the Texas economy and because the mining sector has tended to be a slow growth industry, the Texas industrial production has tended to lag behind the national measure since 1948 . However, exogeneous factors have a particular strong impact on economic activity in Texas. The Suez crisis of 1967 and the growing importance of Department of Defense prime contracts in the national economy and the favorable incidence of these contracts in Texas have accelerated the pace of industrial activity in the state.

An examination of Table III showing a sectoral breakdown of the shift-share components is enlighting because the period February 1961-October 1966 is the last period we have that is largerly free of the influence of Viet Nam. The Texas industrial structure presented by this table shows that in the durable goods industries (the first 11 categories) the industrial mix component is much more important than the regional share component. This is in line with what would be expected historically. However, SIC Codes 32 (stone, clay, glass and concrete products), 36 (electrical machinery) and 19, 38, 39 (miscellaneous manufacturing) all indicate strong competitive or locational advantages for Texas. In the case of miscellaneous manufacturing and stone, clay glass and concrete products we have durable goods industries related to the Texas resource base. The growth in the stone, clay, glass and concrete products industry is associated with the expansion in the concrete products industry which is related to the exploitation of mineral deposits in the state. This mining activity is reflected in SIC Code 14 in Table III. The electrical machine ry industry was the most vigorously growing industry in Texas during this period and reflects the output of electronics components of whichmicrocircuitry has become particularly important. 
The Texas nondurable goods sector has historically had a weak industrial mix growth component and a strong regional share component. However, the regional share effects registered during the February 1961-October 1966 pe riod were weak in the case of both petroleum refining and chemical and allied products. This reflects the growing dependence upon foreign crude oil and the expansion of off-shore drilling activities along the Louisiana Gulf Coast that has tended to diminish the role Texas has historically played in the production and refining of crude oil.

Table III suggests that Texas, in the early part of the 1961 business expansion experienced a favorable industry mixeffect in the durable goods sector. The only exceptions to this were lumber and wood products; and stone, clay, glass and concrete products. In contrast the state generally registered an unfavorable industry mix effect in nondurable manufacturing as well as in mining and public utilities. The regional share or, competitive effect, was unfavorable in 13 of the 23 industrial production categories utilized in the shift analysis. This weakness was pronounced in the durable goods industries with exceptions in the electrical machinery (electronics) industry and in stone, clay, glass, and concrete products.

The shift-share analysis presented in Table III provides the basis for developing a regional industrialization program and to a less extent for the evaluation of such a program. Since the regional share effects may be interpreted as showing the competitive advantage Texas enjoys with respect to the rest of the United States for a particular industry it is possible to use this information to analyze the developmental potential of the state. The overall growth (last colume in Table III) of particular industries does not clearly reflect the locational advantages that industries find in Texas. The regional share effect, however, presumably isolates the competitive or locational advantage that the state has with regard to a particular industry. For this reason a stagewide industrial development program would find it desirable to concentrate its promotionalactivities on industries likely to have a locational advantage in Texas. A review of Table III suggests that electrical machinery (SIC 36), miscellaneous manufacturing (SIC 19 \& 38), apparel (SIC 23), rubber and miscellaneous products (SIC 30), and electric companies and systems (SIC 419) have enjoyed competitive advantages as a result of locating in Texas. It should be noted that only industries having a favorable industrial mix as well as a favorable regional share effect have been included as good industrial development prospects.

Once a group of industries which appear to have locational advantages in the state have been selected itbecomes possible to test these industries against other desirability criterion such as wage rate level, regional linkage or employment stability.

The Texas Industrial Production Index can be used as the raw material for at least a partial approach to vertical analysis. The industrial production time series data can be factor analyzed to determine which of the industrial production series exhibit concomittant movements, that is, to determine which of the production series are linked together.

The quarterly first differences of the 24 Texas Industrial Production Indexes for the period 1956-1966 were factor analyzed in an attempt to determine the degree of association between the movements of the various production series. First differences of the time series were used to eliminate the pervassive nature of trend on the data series. 
Factor analysis partitions the variance of a set of data into independent dimensions. This property of the statistical analysis allows us to determine whether or not a particular production series in "linked" to the other series in the set or not. (See Table V). The element values associated with each variable and each factor may be interpreted as being a partial correlation coefficient; thus, it is valid to say that variables that have high element values with a common factor are associated with one another. For instance the partial correlation coefficient for primary metal industries and factor 2 , is . 71 , and the partial correlation coefficient of fabricated metal products and the same factor is . 80. Thus, the amount of common variance associated with concomittant movements of the two series $(.71) \mathrm{X}(.80)=.57$.

An inspection of Table V indicates that during the period 1956-1966 the industrial structure of the state showedlittle in the way of inter-industry linkages. First of all no single factor accounted for much of the total variance in the set of data. Secondly, with the exception of factor one no other factor shows high element values (partial correlation coefficients) with a large number of production series. It should be noted that although two industries have high partial correlation coefficients with a particular factor, this does not mean that this relationship reflects input-output relationships at the local level. This association may simple mirror common patterns of final demand at the national level. It would seem that a desirable end of regional industrial development policy would be to produce a set of industries that are closely linked together. The factor analysis of industrial production index series would be one way of measuring such linkage.

\section{$\underline{\text { Conclusion }}$}

It has been the purpose of this paper to present a regional production index that is a meaningful estimate of regional industrial activity and at the same time relatively easy measure of construct. It would seem that regional planning, the future development of regional theory, as well as the testing of regional economic activity are developed. And it appears the regional production indexes might serve as both a "vertical" and "horizontal" tool of regional analysis.

The evaluation of regional development programs involve two rathe $\mathrm{r}$ distinct types of analysis. One form of analysis aims at identifying the benefits and costs associated with the undertaking of a particular project. The second form of analysis is generally of a descriptive nature and is used as a means of obtaining a overview of the regional economy. This second form of analysis is useful in putting benefit-cost and feasibility studies of particular projects into proper perspective with regard to the rest of the regionaleconomy. The analytical techniques associated with vertical and horizontal analysis discussed in this paper are useful in providing a general regional framework in which to judge the economic importance of particular industries. Such general tools of regional analysis, in conjunction with feasibility studies of specific firms, constitute the analysis necessary for rational industrial development programs. 
Table I. Data Used To Weight The Texas Industrial Production Index

Actual

Weighting Pattern

Percentage

Distribution

Industry or sector

Total Industrial Production

Total Manufactures

Durable Manufacturers

SIC 24 Lumber and wood products

25 Furniture and fixtures

32 Stone, Clay, \& glass products

33 Primary metals

$34=$ Fabricated metal products

35 Machinery, except electrical

36 Machinery, electrical

37 Transportation equipment

39 Other durable goods_

Nondurable Manufacturers

SIC 20 Food and kindred products

22 Textile mill products

23 Apparel and related products

26 Paper and allied products

Printing and publishing

1963

Unadjusted

Value Added

Percentage

Distribution $1963 \quad 1958$

\begin{tabular}{|c|c|c|c|c|}
\hline & & 100.0 & 100.0 & 100.0 \\
\hline & & 55.9 & 60.6 & 56.2 \\
\hline 40.0 & 41.3 & 38.7 & 41.9 & \\
\hline 3.8 & 3.5 & 3.9 & 3.7 & \\
\hline $\begin{array}{r}3.3 \\
10.0\end{array}$ & $\begin{array}{r}3.2 \\
10.5\end{array}$ & $\begin{array}{r}2.8 \\
11.1\end{array}$ & $\begin{array}{r}3.2 \\
11.2\end{array}$ & \\
\hline 14.9 & 14.8 & 14.0 & 14.1 & \\
\hline 11.4 & 10.5 & 11.5 & 11.3 & \\
\hline 21.3 & 20.5 & 18.5 & 17.9 & \\
\hline 4.3 & 4.9 & 10.9 & 4.4 & \\
\hline 27.5 & 26.6 & 22.4 & 28.8 & \\
\hline 3.5 & 5.5 & 5.1 & 5.3 & \\
\hline
\end{tabular}

28 Chemicals and allied products $31.5 \quad 36.9 \quad 38.3 \quad 36.0$

$\begin{array}{llll}60.0 & 58.7 & 61.3 & 58.1\end{array}$

$\begin{array}{llll}24.6 & 23.3 & 21.4 & 24.3\end{array}$

$\begin{array}{llll}1.0 & 1.2 & .9 & 1.1\end{array}$

$\begin{array}{llll}4.8 & 4.6 & 4.8 & 4.8\end{array}$

$\begin{array}{llll}3.4 & 4.1 & 3.4 & 3.9\end{array}$

$\begin{array}{llll}7.5 & 7.1 & 6.6 & 7.2\end{array}$

$\begin{array}{lllll}\text { Petroleum and coal products } & 24.9 & 20.3 & 22.1 & 20.3\end{array}$

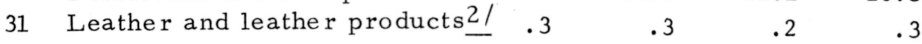

Minerals

SIC131 Crude petroleum

$131 \mathrm{~A}$ Natural gas

132 Natural gas liquids

12, Stone and earth minerals

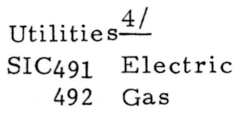

\begin{tabular}{rrrrr}
\multicolumn{2}{c}{37.4} & 37.4 & 31.9 & 36.9 \\
76.7 & 82.7 & 74.4 & 82.2 & \\
11.1 & 4.4 & 11.6 & 4.6 & \\
9.3 & 9.7 & 11.0 & 9.9 & \\
2.9 & 3.2 & 3.1 & 3.2 &
\end{tabular}

\begin{tabular}{rrrrr}
\multicolumn{1}{l}{6.2} & \multicolumn{1}{l}{6.7} & \multicolumn{1}{l}{7.5} & 6.9 \\
59.2 & 59.4 & 66.6 & 59.2 & \\
40.8 & 40.6 & 33.4 & 40.8 &
\end{tabular}

1 This category includes instruments (SIC 38) and ordiance (SIC 19).

2 This category is footwear, except rubber (SIC 314).

${ }^{3}$ This category includes rubber and plastic products.

${ }^{4}$ Value added for utilities was calculated by the Federal Reserve Bank of Dallas.

Source: 1963 and 1958 Census of Manufactures.

Census of Mineral Industries.

Federal Reserve Bank of Dallas. 
Table II. Standard Errors As A Percent Of The Numerator Of The Labor Productivity Factors Used In The Texas Industrial Production Index 1956-1963

\begin{tabular}{|c|c|c|c|c|c|c|c|c|c|}
\hline \multicolumn{10}{|l|}{ SIC } \\
\hline Code & Industry & $1956^{1}$ & 1957 & $1958^{2}$ & 1959 & 1960 & 1961 & 1962 & $1963^{2}$ \\
\hline 20 & Food and Kindred products & 4 & 2 & - & 2 & 2 & 3 & 3.5 & - \\
\hline 22 & Textile mill products & 12 & 2 & - & 5 & 5 & 7 & 9.5 & - \\
\hline 23 & Apparel and allied products & 7 & 5 & - & 2 & 2 & 4 & 5.5 & - \\
\hline 24 & Lumber and wood products & 8 & 6 & - & 6 & 6 & 8.5 & 10.5 & - \\
\hline 25 & Furniture and fixtures & 7 & 5 & - & 3 & 3 & 4.5 & 12.3 & - \\
\hline 26 & Pape $r$ and allied products & 5 & 2 & - & 2 & 2 & 2.5 & 3 & - \\
\hline 27 & Printing and publishing & 12 & 4 & - & 1 & 1 & 1.5 & 4.7 & - \\
\hline 28 & Chemicals and allied products & 3 & 1 & - & 1 & 1 & 1.5 & 2 & - \\
\hline 30 & Other nondurables & - & - & - & 2 & 2 & 3 & 4 & - \\
\hline 31 & Leathe $\mathrm{r}$ and leathe $\mathrm{r}$ products & 9 & 7 & - & - & - & - & - & - \\
\hline 32 & Stone, clay, and glass products & 8 & 5 & - & 7 & 7 & 9.5 & 10.5 & - \\
\hline 33 & Primary metals & 4 & 2 & - & 2 & 2 & 2.5 & 3 & - \\
\hline 34 & Fabricated metal products & 9 & 6 & - & 2 & 2 & 3 & 4.5 & - \\
\hline 35 & Machinery (except electrical) & 7 & 5 & - & 1 & 1 & 1.5 & 2.7 & - \\
\hline 36 & Electrical machinery & - & 2 & - & 5 & 5 & 5.5 & 6 & - \\
\hline 37 & Transportation equipment & 3 & 2 & - & 1 & 1 & 1.5 & 2 & - \\
\hline 38 & Instruments & - & - & - & 7 & 7 & 10 & 10 & - \\
\hline 39 & Misscellaneous & - & - & - & - & - & - & - & - \\
\hline
\end{tabular}

1 The 1956 error terms are based on 1955 standard error with two percentage points added to each 1956 standard error.

${ }^{2}$ Complete enume ration. 
Table III. Shift-Share Components Of The Texas Industrial Production

Index--February 1961 To May 1966 (Base Period $=1957-1959)$

\begin{tabular}{|c|c|c|c|c|c|c|c|}
\hline \multirow{2}{*}{$\begin{array}{l}\text { SIC } \\
\text { Codes }\end{array}$} & \multirow[b]{2}{*}{ Industry Groups } & \multicolumn{3}{|c|}{ Index Numbers } & \multicolumn{3}{|c|}{ ndex Number Changes } \\
\hline & & $\begin{array}{l}\text { Feb. } 1961 \\
\text { Index }\end{array}$ & $\begin{array}{l}\text { May } 1966 \\
\text { Index }\end{array}$ & $\begin{array}{l}\text { National } \\
\text { Growth }\end{array}$ & $\begin{array}{c}\text { Industrial } \\
\text { Mix }\end{array}$ & $\begin{array}{l}\text { Regional } \\
\text { Share }\end{array}$ & $\begin{array}{l}\text { Total } \\
\text { Change }\end{array}$ \\
\hline 24 & Lumber and wood products & & & & & & \\
\hline 24 & except furniture & 96.4 & 133.3 & 49.1 & -21.3 & 9.1 & 36.9 \\
\hline 25 & $\begin{array}{l}\text { Furniture and fixtures } \\
\text { Stone, clay, glass and }\end{array}$ & 90.4 & 134.1 & 46.0 & -11.2 & 13.6 & 43.7 \\
\hline 32 & concrete products & 105.0 & 152.9 & 53.4 & -16.9 & 11.3 & 47.9 \\
\hline 33 & Primary metal industries & 104.5 & 149.1 & 53.2 & 31.4 & -39.9 & 44.6 \\
\hline 34 & Fabricated metal products & 134.4 & 199.9 & 68.4 & 21.2 & -24.2 & 65.4 \\
\hline 35 & Machinery, except electrical & 92.7 & 143.3 & 47.2 & 22.2 & -18.8 & 50.6 \\
\hline 36 & Electrical machinery & 213.3 & 563.9 & 108.6 & 36.9 & 205.2 & 350.6 \\
\hline 37 & Transportation equipment & 87.4 & 148.8 & 44.5 & 21.6 & -4.7 & 61.4 \\
\hline $19,38,39$ & Miscellaneous manufacturing & 77.4 & 172.5 & 39.4 & 0.4 & 55.3 & 95.1 \\
\hline 20 & Food and Kindred products & 110.2 & 125.1 & 56.1 & -39.2 & -2.0 & 14.9 \\
\hline 22 & Textile mill products & 87.4 & 136.2 & 44.5 & -3.8 & 8.1 & 48.8 \\
\hline 23 & Apparel & 102.6 & 175.1 & 52.2 & -10.8 & 31.1 & 72.5 \\
\hline 26 & $\begin{array}{l}\text { Paper and allied products } \\
\text { Printing, publishing and }\end{array}$ & 123.0 & 165.1 & 62.6 & -9.5 & -11.1 & 42.1 \\
\hline 27 & allied industries & 105.0 & 127.4 & 53.4 & -22.6 & -8.5 & 22.4 \\
\hline 28 & Chemicals and allied products & 118.6 & 194.0 & 60.4 & 18.3 & -3.2 & 75.4 \\
\hline 29 & Petroleum refining & 109.2 & 118.1 & 55.6 & -35.7 & -10.9 & 8.9 \\
\hline 31 & Leather and Leather products & 79.7 & 107.9 & 40.6 & -29.5 & 17.1 & 28.2 \\
\hline 30 & Rubber and miscellaneous products & 102.0 & 204.8 & 51.9 & 45.3 & 5.6 & 102.8 \\
\hline
\end{tabular}


Table III. Shift-Share Components Of The Texas Industrial Production

Index--February 1961 To May 1966 (Base Period = 1957-1959) Continued

\begin{tabular}{|c|c|c|c|c|c|c|c|}
\hline \multirow{3}{*}{$\begin{array}{l}\text { SIC } \\
\text { Codes }\end{array}$} & \multirow[b]{3}{*}{ Industry Groups } & \multicolumn{3}{|c|}{ Index Numbers } & \multicolumn{3}{|c|}{ ndex Number Changes } \\
\hline & & Feb. 1961 & May 1966 & National & Industrial & Regional & Total \\
\hline & & Index & Index & Growth & Mix & Share & Change \\
\hline 131 & Crude Petroleum & 93.0 & 110.8 & 47.3 & -29.3 & -0.3 & 17.8 \\
\hline $131 \&$ & $\begin{array}{l}\text { Natural gas } \\
\text { Natural gas liguids }\end{array}$ & 114.6 & 137.3 & 58.3 & -21.0 & -14.7 & 22.7 \\
\hline $\begin{array}{l}14 \\
491\end{array}$ & Nonmetalic minerals except fuels & 1287 & 122.5 & 51.8 & -33.0 & $\begin{array}{r}1.9 \\
27.5\end{array}$ & 20.8 \\
\hline 492 & Gas companies and systems & & & & & & \\
\hline & $\begin{array}{l}\text { Major Sectors } \\
\text { Durables }\end{array}$ & $\begin{array}{l}109.4 \\
102.4\end{array}$ & $\begin{array}{l}131.8 \\
184.4\end{array}$ & $\begin{array}{l}55.7 \\
59.5\end{array}$ & $\begin{array}{r}-16.8 \\
17.6\end{array}$ & $\begin{array}{r}-16.4 \\
4.9\end{array}$ & $\begin{array}{l}22.4 \\
82.0\end{array}$ \\
\hline & Non-Durables & 111.8 & 155.4 & 64.9 & -11.8 & -9.5 & 43.6 \\
\hline & $\begin{array}{l}\text { Mining } \\
\text { Utilities }\end{array}$ & $\begin{array}{r}96.6 \\
120.8\end{array}$ & $\begin{array}{l}115.9 \\
186.9\end{array}$ & $\begin{array}{l}56.1 \\
70.2\end{array}$ & $\begin{array}{r}--34.4 \\
-11.0\end{array}$ & $\begin{array}{r}-2.4 \\
6.9\end{array}$ & $\begin{array}{l}19.3 \\
06.1\end{array}$ \\
\hline
\end{tabular}


Table IV. Average Monthly Incremental Changes Of Industry Mix And

Regional Share Components Of Texas Industrial Production Index

For Major Sectors For Five Expansion Periods Since 1948*

October 1948-July 1953

August 1954-July 1957

April 1958-May 1960

February 1961-October 1966

October 1966-December 1967 **

\section{Expansion Average}

$\begin{array}{rrrrrrrr}.313 & -.013 & -.358 & .191 & .096 & -.073 & .036 & .282 \\ .043 & .217 & -.080 & .208 & -.068 & .174 & .251 & -.006 \\ .546 & -.842 & -.058 & -.012 & -.225 & .138 & .004 & -.112 \\ .259 & .072 & -.174 & -.140 & -.506 & -.035 & -.162 & .03 \\ -.250 & 2.364 & .078 & .921 & .007 & .457 & 1.428 & .457 \\ .290 & -.140 & . .170 & .060 & -.0180 & -.020 & .030 & .070\end{array}$
iness expansion so that the components will be comparable over time.

* * Reflects the early impact of Viet Nam. 
Table V. Factor Analysis Of Industry Groups (First Differences)

Of The Texas Industrial Production Index (1956-1966)*

SIC Code

20

22

23
Industry Name

Mining and quarrying, non-metallic, except fuel

Food and Kindred Products

Textile Mill Products

Apparel

Lumber and Wood Products

Furniture and Fixtures

Pape $r$ and Allied Products

Printing, Publishing and Allied Industries

Chemicals and Allied Products

Petroleum, Refining and Related Industries

Rubber and Miscellaneous Plastic Products

Leathe $r$ Products

Stone, Clay, and Glass Products

Primary Metal Industries

Fabricated Metal Products

\begin{tabular}{|c|c|c|c|c|c|c|c|c|c|c|}
\hline & & & & actors & & & & & & \\
\hline 1 & 2 & 3 & 4 & 5 & 6 & 7 & 8 & 9 & 10 & $\mathrm{~h}^{2}$ 决珰 \\
\hline-.12 & -.04 & .09 & .27 & .69 & .33 & -.15 & -.07 & .17 & .54 & 1.00 \\
\hline .12 & -.79 & -.47 & -.12 & .17 & -.25 & -.09 & .07 & -.06 & .17 & 1.00 \\
\hline .42 & .45 & -.35 & -.28 & .12 & -.17 & .12 & $\ldots 16$ & -.29 & .19 & .78 \\
\hline .38 & .66 & -.12 & .04 & -.09 & .23 & .30 & .18 & .37 & -.01 & .90 \\
\hline .59 & -.13 & -.24 & -.12 & .60 & -.14 & -.06 & .35 & .14 & -.12 & .99 \\
\hline .71 & .05 & -.17 & -.31 & .06 & -.19 & .49 & -.12 & .38 & -.09 & 1.00 \\
\hline .35 & .38 & -.29 & .12 & -.34 & .38 & -.08 & .56 & -.21 & -.12 & 1.00 \\
\hline .62 & -.74 & -.24 & .17 & -.12 & .13 & .19 & -.12 & .15 & -.01 & 1.00 \\
\hline .47 & .13 & -.11 & -.42 & .42 & .28 & -.37 & -.27 & .01 & -.34 & 1.00 \\
\hline .56 & -.37 & .00 & .59 & -.07 & -.05 & -.27 & -.15 & -.28 & -.16 & 1.00 \\
\hline .71 & -.23 & -.41 & .18 & .05 & -.09 & .05 & .23 & -.28 & .14 & .93 \\
\hline .57 & -.66 & .03 & -.47 & -.02 & .29 & .02 & .23 & .02 & .06 & 1.00 \\
\hline .29 & .13 & .47 & -.03 & .18 & .10 & .60 & -.02 & -.34 & .03 & .84 \\
\hline .38 & .71 & -.10 & .31 & .12 & .33 & .00 & -.24 & -.18 & .09 & .98 \\
\hline .27 & .80 & -.07 & -.05 & .36 & -.14 & .06 & .00 & -.13 & -.14 & .91 \\
\hline
\end{tabular}


Table V. Factor Analysis Of Industrial Groups (First Differences)

Of The Texas Industrial Production Index (1956-1966)* Continued

35 Machinery, except Electrical

Electrical Machinery, Equipment

36 and Supplies

$19,38,39$ Ordnance, Instruments, Miscellaneous

131

Crude Petroleum

$\begin{array}{lrr}\ldots & .70 & -.11 \\ \ldots & .26 & .17 \\ \ldots & .16 & .64 \\ \ldots & .50 & -.20 \\ \ldots & .65 & .29 \\ \ldots & .53 & .19 \\ \ldots & .65 & -.04 \\ \ldots & .64 & -.13 \\ \ldots & .33 & -.01 \\ \ldots & 5.87 & 4.42 \\ \cdots & & \end{array}$

$\begin{array}{rr}-.80 & .00 \\ -.68 & -.28 \\ -.13 & -.29 \\ .34 & -.39 \\ .15 & .60 \\ & \\ .54 & -.40 \\ .02 & .63 \\ .67 & -.09 \\ .85 & -.03 \\ 3.09 & 2.44\end{array}$

$\begin{array}{rrrr}.22 & .06 & -.06 & -.31 \\ -.32 & -.03 & -.39 & -.21 \\ -.13 & -. .34 & -.29 & -.19 \\ -.18 & -.13 & .25 & -.35 \\ -.17 & -.23 & -.06 & -.08 \\ -.19 & -.19 & .32 & .22 \\ .04 & -. .38 & -.01 & -.03 \\ .19 & -.14 & -17 & -.17 \\ -.13 & .13 & -.30 & .34 \\ 1.69 & 1.55 & 1.53 & 1.29\end{array}$

.11

.11

1.00

131A Natural Gas

132 Natural Gas Liquids

491 Electric Companies \& Systems

Gas Companies \& Systems

Sum of Squares of Factors

$\cdots$

3.09

1.691 .55

$-.03$

.04
.26

.94

Sum of Squares of Communalities

Source: Federal Reserve Bank of Dallas

* Data is seasonally adjusted quarterly time series.

; The communality or $\mathrm{h}^{2}$, shows the percentage of total variation of a particular variable accounted for by the factor analysis.

individual communalities will not equal the sum of squares of communality because of rounding. 
1

IJ. R. Meyer, "Regional Economics: A Survey (With Bibliography)" American Economic Review, LIII, (March 1963), pp. 19-54;

D. C. North, "Location Theory and Regional Economic Growth, " Journal of Political Economy, LXIII, (June 1955), pp. 243-58;

Harvey S. Perloff, Edgar S. Dunn, Jr., Eric E. Lampard, and RichardF. Muth: Regions, Resources, and Economic Growth (Baltimore: The John Hopkins Press, 1960):

William H. Nicholls, "Southern Tradition and Regional Economic Progress.' Southern Economic Journal, XXVI, (January 1960), pp. 187-198;

Bernard Okum and Richard W. Richardson, "Regional Income Inequality and Internal Population Migration," Economic Development and Cultural Change, IX, (January 1961), pp. 128-143;

Albert O. Hirschman, The Strategy of Economic Development, (New Haven: Yale University Press, 1958), pp. 183-201;

John Friedman and William Alonso, Regional Development and Planning, (Cambridge: The MIT Press, 1964).

2

The published discussion of regional industrial production indexes has been conspicuous by its absence in recent conferences dealing with the problem of regional accounts, see:

Werner Hochwald, Design of Regional Accounts, (Baltimore: John Hopkins Press, 1961); Werner Z. Hirsch, Elements of Regional Accounts, (Baltimore: John Hopkins Press, 1964.

${ }^{3}$ Several Bureaus of Business Research, associated with universities, have developed, or publish, regional industrial production indexes. In addition, at least four of the Federal Reserve Banks (Dallas, Atlanta, Boston, and Minneapolis) have experimented with or have institutionalized a state or regional industrial production index. The various companies of the Bell Telephone System have also developed state industrial production indexes.

${ }^{4}$ A recent article has discussed this problem, but unfortunately the authors used national coefficients to determine both the state expenditures and the state weights for their industrial production index. A hazardous practice at best; see:

John W. Kendrick and C. Milton Jaycox, "The Concept and Estimation of Gross State Product," Southern Economic Journal, XXXII, (October 1965), pp. 153 168; Also see: Harry Benjamin Ernst, "An Index of Manufacturing Production in New England," Journal of the American Statistical Association, Vol. 53 (June 1958), pp. 336-347.

${ }^{5}$ A state industrial production index would be a useful tool to use inconjunction with a regional input-output study. Furthermore, the industrialproduction subindexes couldfurnish a dynamic measure of the states' industrial structure. This dynamic approach could be achieved by factor analysizing the subindexes of the regionalindustrial production index. The result of this analysis would be a description of the industrial linkages within the state. The P-technique, used to factor analysize time series would be appropriate in this case. Complete discussions of this technique are found in:

Benjamin Fruchter, Introduction to Factor Analysis, (Princeton: D. Van Nosstrand Company, Inc.), 1954;

R. B. Cattell and M. Adelson, "The Dimension of Social Change in the U.S.A. as determined by P-technique," Social Forces, 30(1951), pp. 190-201.

${ }^{6}$ We rner Hochwald, op. cit., p. 259. 
7

At present a number of states are already publishing economic indicators--containing the type of basic information used in the construction of an industrial production index. The Bureau of Employment Security and State Universities, (and state agencies) have taken the lead on institutionalizing economic indictor series to date.

See :

Harry F. Stark, "Report on State Economic Indicator Projects," Interstate Conference on Labor Statistics, Chicago, June 16, 1966.

One of the mostfruitful approaches to regional data collection is being undertaken by the Board of Governors of the Federal Reserve System. The Federal Reserve is assembling electrical power consumption data by 3 and 4 digit SIC codes at the state level, on a monthly basis. The prefection of this sys tem of data collection will present a basic break through in industrial data gathering. Employment data, of course, has been collected for many years on this basis. However, employment information is generally released only at the 2 digit SIC level. This represents too high a degree of aggregation for the analysis of many problems.

${ }^{8}$ Richard B. Andrews, "Economic Planning for Small Areas, ${ }^{2}$ LandEconomics, XXXIX (May, 1963).

${ }^{9}$ The Federal Reserve Bank of Minneapolis developed a revised industrial/production indexusing a set of national coefficients de rived by regression analysis. The estimating equation takes the form of the Cobb-Douglas production function, $\mathrm{Y}=\mathrm{AL}^{\mathrm{a}} \mathrm{K}^{\mathrm{B}}$, where:

$\mathrm{Y}=$ Federal Reserve Board Production Index,

$\mathrm{L}=$ Production worke $\mathrm{r}$ manhours,

$\mathrm{K}=$ Electricity (general industrial).

The resulting aggregate estimating equation took on the following values:

$$
\mathrm{Y}=-.608 \mathrm{~L} \cdot{ }^{364} \mathrm{~K} \cdot 745
$$

These national coefficients we re then applied to district manhours and electricity power series to arrive at an estimate of districtindustrial production. But as the author pointed out this aggregate approach does not take into account differences in industrial composition between the District and Nation. For a more complete discussion of the Cobb-Douglas approach see: "Toward an Index of Ninth District Indus 1 Production, " Monthly Review, Federal Reserve Bank of Minneapolis, (June 1966), pp. 3-8.

${ }^{10}$ The importance of the "competitive" effect has been made clear in.numerous studies see:

Daniel Creamer, "Shifts of Manufacturing Industries," Industrial Location and National Resources, (Washington: USGPO) 1943, pp. 85-104;

Harvey S. Porloff, et.al., Regions, Resources and Economic Growth, (Baltimore: The John Hopkins Press, 1960), pp. 295-306;

Lowell D. Ashby, Regional Change in a National Setting, staff wo rking paper in Economics and Statistics, No. 7, Office of Business Economics, April, 1964.

Edgar S. Dunn, Jr., "A Statistical and Analytical Technique for Regional Analysis," Regional Science Association Papers and Proceedings, VI(1960) 97-112.

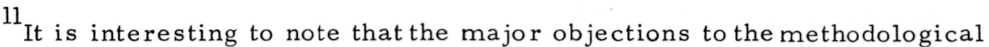
approach of economic basic studies is that this technique glosses over problems involving diffe rent production and consumption patterns between the nat- 
ion and the region. Thus, much of this agrument can be applied here, see: Richard B. Andrews, "The Mechanics of the Urban Economic Base," Land Economics, XXXIX (continuing series). Particularly: RichardB. Andrews, "Mechanics of the Urban Economic Base: General Problems of Identification," Land Economics, XXX (May 1955), pp. 164-172.

12 The techniques utilized in obtaining the sample which limits its usefulness are discussed in:

Dorothy Hinton, "New Benchmark Levels for BLS Establishment Employment Estimates," Employment and Earnings, (September 1963) Bureau of Labor Statistics, U.S. Department of Labor; Bureau of Labor Statistics, Guide to Employment Statistics of BLS, USDL, 1961; David M. Fishbein, Measurement of Employment, Hours, and Earnings in Non-agricultural Industries, USDL, (November 1961).

${ }^{13}$ The Texas Industrial Production Index contains 24 subindexes, 18 of the subindexes are based upon manhours data obtained from the Texas Employment Commission. Six of the subindexes a re based on actual production data. Actual production data for the mining industry is obtained from the American Petroleum Institute and the Bureau of Mines. Production data for the Electric Utility and Gas Utility industries is obta ined from the Federal Power Commission and the Texas Railroad Commission.

${ }^{14} \mathrm{~A}$ bette $\mathrm{r}$ method of computing the numerator for states and regions is to combine published census value added data and unpublished census cost of materials figures. When added together these two categories yield a figure representing value of shipments, plus net change ininventories, plus merchandising operations. In other words value of output.

${ }^{15}$ Carl W. Harl, Methodology of the Texas Industrial Production Index (1966 Revision), mimeographed (available through Research Department, Federal Reserve Bank of Dallas, ) pp. 7-10.

${ }^{16}$ Thomas A. Wilson and Otto Eckstein, "Short-run Productivity Behavior in U.S. Manufacturing, "Review of Economics and Statistics, XLVI, (February, 1964), pp. 41054.

17 An extensive discussion of the weighting problem is found in:

Clayton Gehman and Cornelia Motheral, Industrial Production Measurement in the United States: Concepts, Uses, and Compilation Practices, Board of $\overline{G o v e r} \overline{n o r s}$ of the Federal Rese rve System, (February $\overline{1964), ~ p p}$. 5-16. An account of the adjustment applied where value added weights a re used is found in:

Edward A. Manookian, Industrial Production 1957-1959 Base (Washington: Board of Governors of the FederalReserve System), p. 2; and Industrial Production 1959 Revision, (Washington: Board of Governors of the Federal Reserve System), 1960, pp. 30-38.

${ }^{18} \mathrm{~A}$ Critical evaluation of shift analysis is found in the following citations: David B. Houston, "The Shift and Share Analysis of Regional Growth. A Critique, "Southern Economic Journal, XXXIII (April 1967), pp. 577-581; Lowell D. Ashley, "The Shift-Share Analysis: A Reply," Southern Economic Journal XXXIV (January 1968), pp. 423-425; and James Brown, "Shift and Share Projections of Regional Economic Growth: An Empirical Test," Journal of Regional Science, Vol. 9 (1969), pp. 1-17.

For additional discussion of shift analysis see: Lowell D. Ashby, "Growth Patterns in Employment by County, 1940-1950 and 1950-1960," Survey of Cur- 
rent Business, Vol. 46 (February 1966), pp. 9-13; and Lowell D. Ashby, Regional Change In A National Setting, Staff Working Paper in Economics and Statistics, No. 7, U.S. Department of Commerce. Following Ashby the categories used in shift analysis can be defined:

1. $\mathrm{IP}_{\mathrm{si}} \cdot \mathrm{r}_{\mathrm{nt}}=$ national growth component,

2. $\operatorname{IP}_{\mathrm{si}}\left(\mathrm{r}_{\mathrm{ni}}-\mathrm{r}_{\mathrm{nt}}\right)=$ industrial $\mathrm{mix}$ component,

3. $\operatorname{IP}_{\mathrm{si}}\left(\mathrm{r}_{\mathrm{si}}-\mathrm{r}_{\mathrm{ni}}\right)=$ regional share component,

$4.11)+2)+3$ ) = total growth, given index number points, where;

$\mathrm{IP}_{\mathrm{si}}=$ industrial production of industry, $\mathrm{i}$, for the state, $\mathbf{s}$,

$r_{n t}=$ rate of growth of toal industrial production in the nation,

$\mathrm{r}_{\mathrm{ni}}=$ national rate of growth in industry $i$,

$r_{s i}=$ state rate of growth of industry $i$.

19

Carl W. Hale, "Shift-Share Analysis as a Descriptive Tool in Regional Analysis," Mississippi Valley Journal of Business and Economics, Vol. VI (Spring 1971), pp. 70-74. 